\title{
Tocilizumab in patients with COVID-19: which patient, time, and dose?
}

\author{
Ahmed Hasanin ${ }^{1}\left[\right.$. Maha Mostafa ${ }^{1}$ \\ Received: 2 June 2021 / Accepted: 10 July 2021 / Published online: 15 July 2021 \\ (c) Japanese Society of Anesthesiologists 2021
}

\begin{abstract}
Tocilizumab (TCZ) is a recombinant anti-interleukin-6 monoclonal antibody which showed uprising evidence as an antiinflammatory agent which modulates the cytokine storm in patients with COVID-19. However, proper use of the drug requires selection of the appropriate patient and timing. The two main factors which might improve patient selection are the degree of respiratory failure and systemic inflammation. TCZ can decrease the mortality and progression to invasive mechanical ventilation in patients with severe COVID-19 who are not yet invasively ventilated. However, its use in invasively ventilated patients did not yet gain the same level of evidence especially when administered after $>1$ day from mechanical ventilation. Being an anti-inflammatory and immunomodulatory drug, TCZ was mostly used in patients with COVID-19 who have clear signs of cytokine storm. However, the drug still showed positive response in some studies which did not strictly select patients with elevated markers of systemic inflammation. Thus, it is warranted to investigate and/or re-analyze the role of the drug in patients with severe COVID-19 and with no signs of systemic inflammation. TCZ is used in a dose of $8 \mathrm{mg} / \mathrm{kg}$ which can be repeated if there was no clinical improvement. However, there are no clear criteria for judgment of the success of the first dose. Being a drug with a major effect on gross outcomes in a serious pandemic with millions of mortalities, TCZ should be meticulously investigated to reach definitive indications and number of doses to avoid drug overuse, shortage, and side effects.
\end{abstract}

Keywords Tocilizumab $\cdot$ COVID-19 $\cdot$ SARS-CoV-2

\section{Background}

Coronavirus disease-2019 (COVID-19) represents a major health threat with $\approx 3$ million worldwide mortalities and with few effective drugs [1]. COVID-19 is characterized by an excessive host inflammatory response with a surge of proinflammatory cytokines such as interleukin- 6 causing sepsis, acute respiratory distress syndrome and multiorgan failure [2]. Therefore, the use of immunomodulatory drugs was able to improve patient outcomes. Dexamethasone was the first immunomodulatory agent which decreased mortality in patients with COVID-19 [3]. Interlukin-6 has an important role in the cytokine storm by promoting helper $\mathrm{T}$ cell response and inhibit regulatory $\mathrm{T}$ cell [2]. Tocilizumab

Ahmed Hasanin

ahmedmohamedhasanin@gmail.com

Maha Mostafa

maha.mostafa@cu.edu.eg

1 Department of Anesthesia and Critical Care Medicine, Faculty of Medicine, Cairo University, 01 elsarayah street, Elmanyal, Cairo, Egypt
(TCZ) is a recombinant anti-interleukin-6 monoclonal antibody that block interlukin- 6 receptor; and is known to be effective in treating cytokine storm associated with B-cell chronic lymphocytic leukemia [2]. Hence, TCZ is believed to be able to modulate the cytokine storm in patients with COVID-19. The benefit of TCZ is nearly settled in patients with severe COVID-19; however, there is still lack of evidence about the proper choice of patients who would benefit from the drug as well as the proper timing of drug administration. The aim of this work is to provide a simplified comprehensive review for the relevant clinical data for the optimum patient, timing, and regimen for the use of TCZ in patients with COVID-19.

\section{What is current evidence for TCZ in COVID-19?}

There are nine randomized controlled trials (RCTs) which showed non-consistent results for the value of TCZ in COVID-19. The most probable reason for the variable response to the drug in the available studies is the 
heterogenicity of the outcomes, baseline characteristics, and the severity of respiratory failure in the participants as well as the concomitant use of steroids. Hence, in this review, we categorized the trials to a positive or a negative trial depending on the presence of any clinical benefit (improvement in survival and/or disease severity; or reduction in the need to respiratory support). Furthermore, we used the world health organization (WHO) clinical progression scale to describe the degree of respiratory support of the included patients in each trial. According to this scale, patients with COVID-19 are generally divided into ten categories according to the disease severity: uninfected (category 0), infected asymptomatic (category 1), symptomatic independent (category 2), symptomatic dependent (category 3), hospitalized without oxygen (category 4), hospitalized with oxygen by mask or nasal prongs (category 5), non-invasively ventilated or on high-flow nasal cannula (category 6), invasively ventilated up to extra-corporeal membrane oxygenation (categories 7-9), dead (category 10) [4].

Table 1 summarizes the type of patients, mortality, and progression of disease in each trial.

\section{The positive studies}

Five studies showed benefits for the use of TCZ in COVID19. The RECOVERY [5] $(n=4116)$ and REMAP-CAP [6] $(n=895)$ trials included patients with severe COVID-19 on different levels of respiratory support (WHO categories 5-9). Two other smaller trials, namely the CORIMUNOTOCI [7] $(n=131)$ and EMPACTA [8] $(n=389)$ trials, also included patients with severe COVID-19 who were on oxygen therapy but not on invasive mechanical ventilation (WHO category 5 [7] and categories 4-6 [8]). The COVINTOC study [9] $(n=179)$ included a mix of moderate and severe patients (WHO categories 4-9) who were mostly not receiving invasive ventilation (only $5 \%$ of the participants were invasively ventilated at randomization).

\section{The negative studies}

On the other side, four RCTs with 933 total number of patients, which are smaller than the positive studies, showed no advantage for the use of TCZ compared to placebo on patient outcomes. The first two trials, the TOCIBRAS [10] $(n=129)$ and COVACTA [11] $(n=438)$ studies, included patients on various modes of respiratory support starting from simple $\mathrm{O}_{2}$ therapy up to invasive mechanical ventilation (WHO categories 5-9). The BACC-Bay trial [12] $(n=243)$ did not include patients requiring supplementary $\mathrm{O}_{2}>10$ $\mathrm{L} / \mathrm{min}$ and $15 \%$ of the participants were not receiving $\mathrm{O}_{2}$ therapy (WHO categories 4,5). The RCT-TCZ-COVID-19 [13] study $(n=123)$ included patients who require supplementary $\mathrm{O}_{2}$ including high-flow oxygen but did not include those who required other modes of non-invasive ventilation (WHO categories 5,6).

\section{Which patient would benefit from TCZ?}

Reaching the maximum benefit for TCZ depends on appropriate selection of the patient and the window of drug administration. The two main factors which impact the decision are the severity of respiratory failure as well as the extent of systemic inflammation.

\section{The degree of respiratory failure}

With exception of the REMAP-CAP study [6], the three positive studies shared a common feature which is the clear benefit of TCZ in patients with severe illness who did not receive invasive mechanical ventilation. The CORIMUNOTOCI [7] and EMPACTA [8] trials strictly excluded patients who received any invasive ventilatory support (WHO categories 7-9). In the COVINTOC trial, despite including casemix (WHO categories 4-9), the post hoc analysis revealed benefit in patients with severe disease (WHO category $>4$ ) in addition only $5 \%$ of the participants were WHO categories 7-9 [9]. The RECOVERY trial [5], despite the presence of invasively ventilated participants (WHO categories 7-9), did not show positive results except in those who were not invasively ventilated (WHO categories 5,6). While those who were invasively ventilated (WHO categories 7-9) did not show improved survival nor reduced duration of ventilation after receiving TCZ. The REMAP-CAP [6] study is the only study which showed positive results in patients who were invasively ventilated (WHO categories 7-9); however, drug administration in this study was very early within $12 \mathrm{~h}$ from admission.

On the other hand, the most common feature in the negative studies is being small and the case-mix regarding the severity of the disease of the included patients (TOCIBRAS and COVACTA studies included patients with WHO categories 5-9 [10, 11], while the BACC-Bay [12] included severe and non-severe cases [WHO categories 4,5]). The only exception is the RCT-TCZ-COVID-19 trial [13] which included nearly a homogenous group of patients (WHO categories 5,6).

According to the available evidence, the patient category who would show maximum benefit from TCZ is category 6 and probably category 5. There are no data to support the use of TCZ in patients with no or low supplementary oxygen requirements (categories 1-4). The use of TCZ in invasively ventilated patients (categories 7-9) did not reduce mortality and did not improve weaning success in the RECOVERY trial [5]. In the REMAP-CAP study [6], TCZ was beneficial in invasively ventilated patients when 


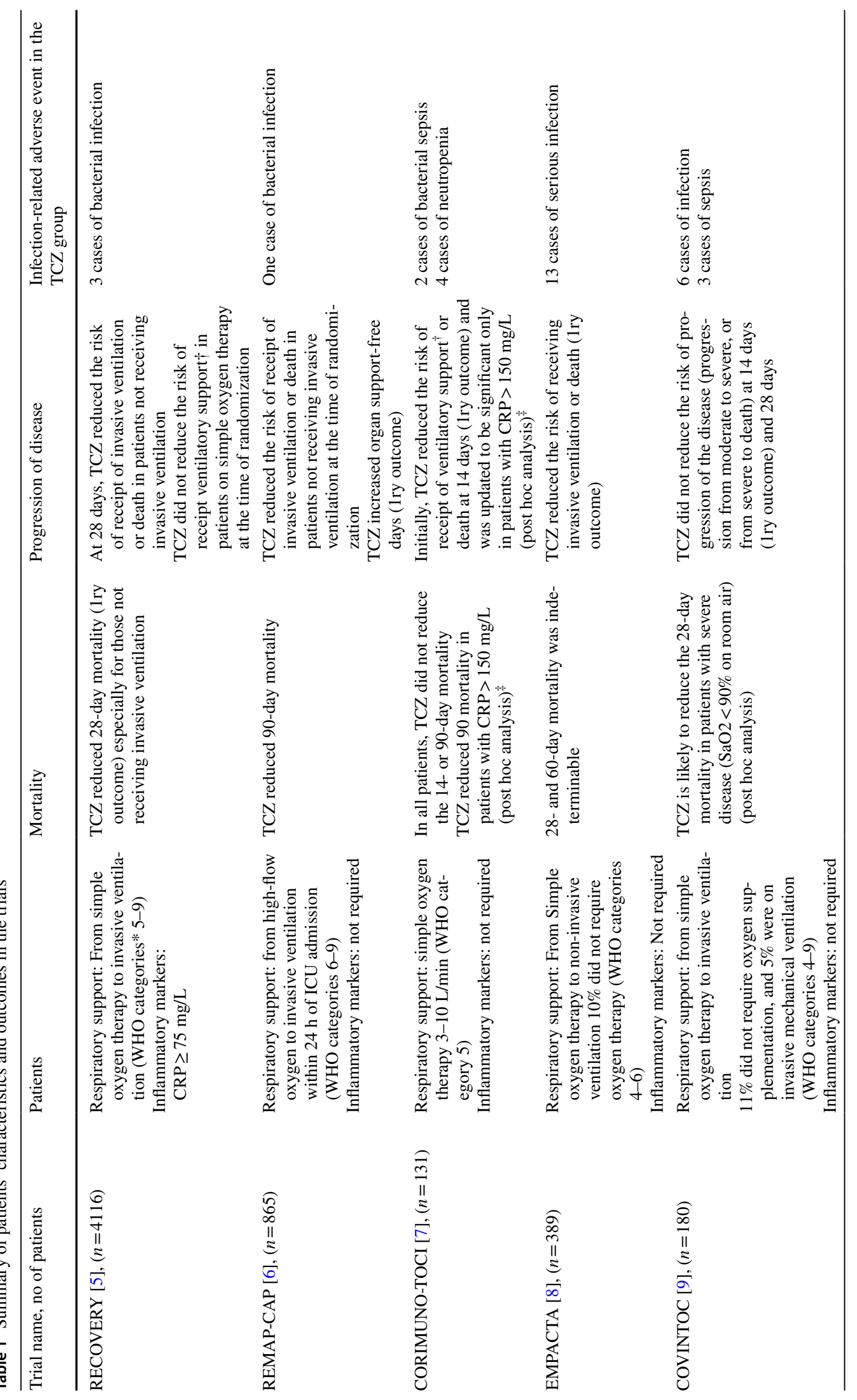




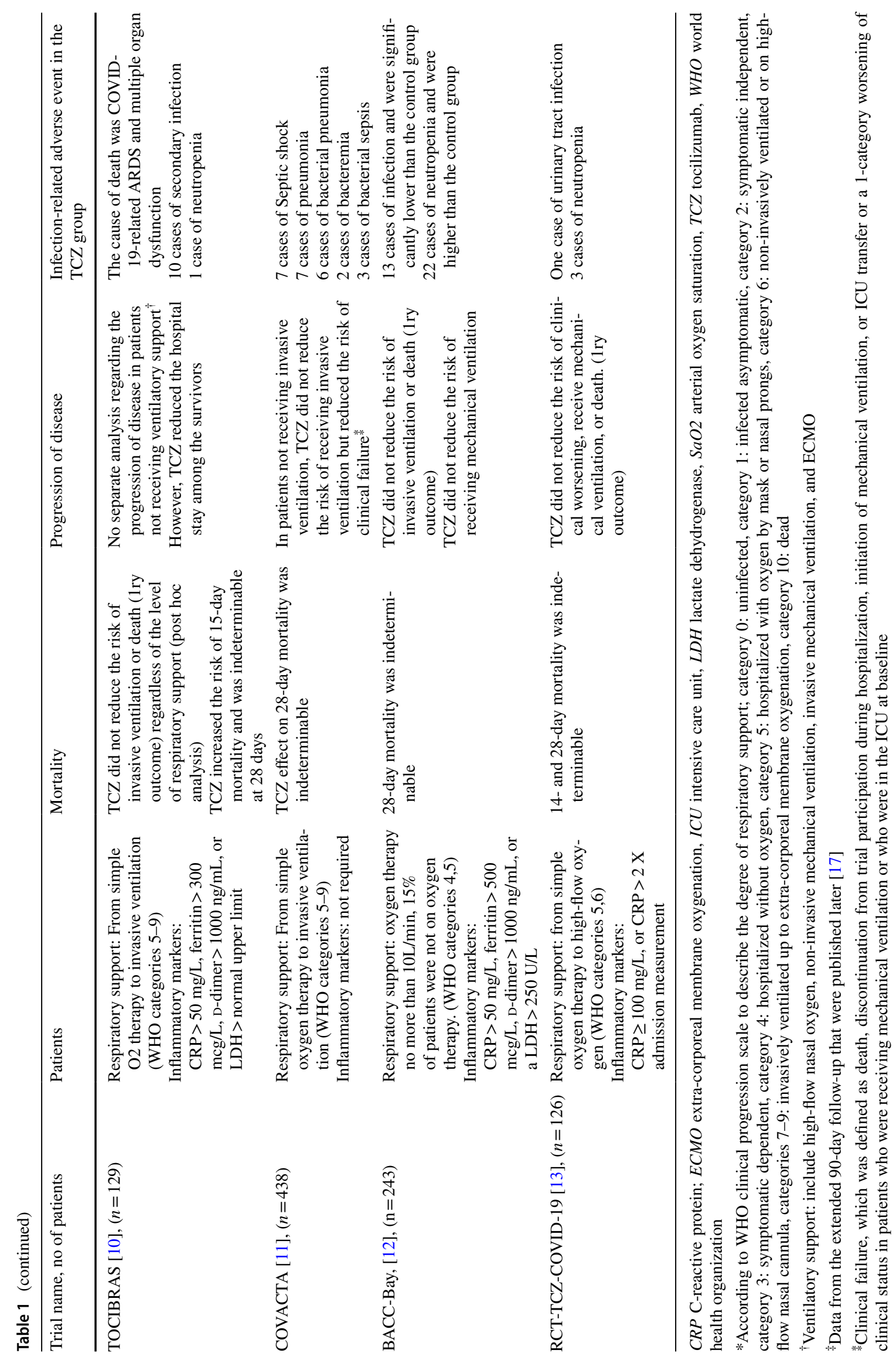


used early within $12 \mathrm{~h}$ from admission. The use of TCZ in invasively ventilated patients in the later phases of the disease required further investigation and/or subgroup analysis in future meta-analyses.

\section{The severity of cytokine storm:}

The benefit of TCZ in patients with COVID-19 is explained by its anti-inflammatory, immunomodulatory actions. However, inclusion of patients in the available RCTs did not strictly include patients with clear cytokine storm. C-reactive protein (CRP) was the most used biomarker for inflammation in the available RCTs. CRP is highly correlating with interlukin-6 level [14], widely available and is associated with the severity and prognosis of the disease $[15,16]$. The RECOVERY [5], TOCIBRAS [10], BACC-Bay [12] and RCT-TCZ-COVID-19 trials clearly included patients with elevated CRP, being the most available marker (the inclusion criteria in those trials was CRP level $>75,50,50$, and $100 \mathrm{mg} / \mathrm{L}$, respectively). The presence of severe inflammation was not necessarily included in the other five RCTs.

The REMAP-CAP study [6] reported that the positive effect of TCZ was greatest in patients with the highest tertile of CRP. The CORIMUNO-TOCI investigation group published updated results of the extended follow-up of their patients and showed that TCZ is beneficial in the subset of patients with CRP level $\geq 150 \mathrm{mg} / \mathrm{L}$ [17]. However, neither of the other studies found any association between the severity of inflammation and the effect TCZ. Therefore, we cannot reach a clear suggestion for the inflammatory criteria upon which drug administration should be decided. A patient with elevated CRP ( $>75-150 \mathrm{mg} / \mathrm{L}$ ) is very likely to benefit from TCZ, while patients with impaired oxygenation and low inflammatory markers require further subgroup analyses and/or new RCTs before declaring a similar benefit for TCZ.

\section{The concomitant use of steroids with TCZ}

Steroids are the most widely used and effective anti-inflammatory and immunosuppressive drugs. Steroids, namely dexamethasone, was the first immunomodulatory drug that reduced mortality in hospitalized patients with COVID-19 and since then, steroids were routinely used in the usual care of the hospitalized patients. The use of steroids was highly variable in the available RCTs mainly depending on the timing of the trial and local protocols. The use of steroids was high in both treatment and control arms in the RECOVERY (99\%), REMAP-CAP (93\%), COVINTOC (91\%) and TOCIBRAS (70\%), and was variable between the TCZ and control arms in the CORIMUNO-TOCI (44\% Vs. 83\%), EMPACTA (55\% Vs. 67\%), COVACTA (33\% Vs. 52\%), and was low in the BACC-Bay (11\% Vs. 6\%) and RCT-TCZ-COVID-19 (nearly $10 \%$ in both groups). There is a very clear evidence that combination of TCZ and dexamethasone has a synergistic effect on patients' outcomes: (1) the studies whose most of the participants received the two drugs showed positive results (the only exception was the TOCIBRAS study) (2) the two studies with low use of steroids showed negative results (3) the subgroup analysis in the RECOVERY trial showed a potential positive effect of the concomitant use of steroid and TCZ. Hence, the proportion of patients receiving steroid drugs might contribute to the variable response to TCZ within the available RCTs.

\section{Infection-related adverse events}

One of the feared side effects of TCZ is exacerbation of infection and sepsis; however, TCZ did not increase the risk of infection or sepsis in comparison to the control arm of the current RCTs. However, it should be noted that patients with suspicion of active viral (other than SARS-CoV-2), bacterial or fungal infection were strictly excluded from the trials. The number of infection-related adverse events in TCZ arm in each trial is reported in Table 1.

\section{Drug administration}

Proper regimen for drug prescription requires selection of the right patient, dose, monitoring of patient response, and determination of patients who require an additional dose.

\section{What is the dose of TCZ in patients with COVID-19?}

With exception of the COVINTOC study [9] which used a dose of $6 \mathrm{mg} / \mathrm{kg}$ with a maximum up to $480 \mathrm{mg}$, nearly all the available studies used the same dose of TCZ which is $8 \mathrm{mg} / \mathrm{kg}$ with a maximum dose of $800 \mathrm{mg}$. (Table 2) However, there is lack of consistency in the number of doses of the drug. The BACC-Bay [12] and TOCIBRAS [10] studies used a fixed single dose regimen while the RCT-TCZCOVID-19 [13] used a fixed double-dose regimen with a 12-h interval between the two doses. All the remaining six RCTs repeated the drug if the patient did not respond positively to the first dose. The second dose was administered within 8-24 h from the first dose in all studies except the CORIMUNO-TOCI study [7] which used $400 \mathrm{mg}, 3$ days after the first dose, and the COVINTOC study [9] which used the second dose within a period of $12 \mathrm{~h}-7$ days from the first dose. It should be noted that the decision of the second dose was mostly left to the physician judgment with no solid definition for "which patient responded adequately to TCZ and did not require an additional dose". The CORIMUNOTOCI study [7] was the only RCT in which the authors clarified the indication of the second dose which is failure of 
Table 2 Summary of drug regimen

\begin{tabular}{|c|c|c|c|}
\hline \multirow[t]{2}{*}{ Trial name } & \multirow[t]{2}{*}{ First dose } & \multicolumn{2}{|l|}{ Second dose } \\
\hline & & Timing & Indication \\
\hline RECOVERY [5] & $\begin{array}{l}800 \mathrm{mg} \text { if weight }>90 \mathrm{~kg} \\
600 \mathrm{mg} \text { if weight } 65-90 \mathrm{~kg} \\
400 \mathrm{mg} \text { if weight } 40-65 \mathrm{~kg} \\
8 \mathrm{mg} / \mathrm{kg} \text { if weight } \leq 40 \mathrm{~kg}\end{array}$ & After $12-24 \mathrm{~h}$ & $\begin{array}{l}\text { If no improvement according to the attending clinician. } 29 \% \\
\text { received a second dose }\end{array}$ \\
\hline REMAP-CAP [6] & $8 \mathrm{mg} / \mathrm{kg}$, maximum of $800 \mathrm{mg}$ & After $12-24 \mathrm{~h}$ & $\begin{array}{l}\text { If no improvement according to the attending clinician. } 29 \% \\
\text { received a second dose }\end{array}$ \\
\hline CORIMUNO-TOCI [7] & $8 \mathrm{mg} / \mathrm{kg}$ & Day 3 & $\begin{array}{l}\text { If oxygen requirement did not decrease by } 50 \% \\
47 \% \text { received a second dose }\end{array}$ \\
\hline EMPACTA [8] & $8 \mathrm{mg} / \mathrm{kg}$, maximum of $800 \mathrm{mg}$ & After 8-24 h & $\begin{array}{l}\text { if no improvement or worsening of clinical state on a 7-point } \\
\text { ordinal scale } \\
27.2 \% \text { patients received a second dose }\end{array}$ \\
\hline COVINTOC [9] & $6 \mathrm{mg} / \mathrm{kg}$ maximum of $480 \mathrm{mg}$ & Within $12 \mathrm{~h}$ to 7 days & If no improvement or worsening clinical state \\
\hline TOCIBRAS [10] & $8 \mathrm{mg} / \mathrm{kg}$, maximum of $800 \mathrm{mg}$ & NA & \\
\hline COVACTA [11] & $8 \mathrm{mg} / \mathrm{kg}$, maximum of $800 \mathrm{mg}$ & After $8-24 \mathrm{~h}$ & $\begin{array}{l}\text { If no improvement or worsening clinical state on a 7-point } \\
\text { ordinal scale } \\
22.1 \% \text { patients received a second dose }\end{array}$ \\
\hline BACC-Bay [12] & $8 \mathrm{mg} / \mathrm{kg}$, maximum of $800 \mathrm{mg}$ & NA & \\
\hline RCT-TCZ-COVID-19 [13] & $8 \mathrm{mg} / \mathrm{kg}$, maximum of $800 \mathrm{mg}$ & After $12 \mathrm{~h}$ & To all patients in TCZ group \\
\hline
\end{tabular}

ECMO extra-corporeal membrane oxygenation, ICU intensive care unit, NA not applicable, TCZ tocilizumab

*7-point ordinal scale: 1: Discharged (or "ready for discharge" as evidenced by normal body temperature and respiratory rate, and stable oxygen saturation on ambient air or $\leq 2 \mathrm{~L}$ supplemental oxygen); 2: Non-ICU hospital ward (or "ready for hospital ward") not requiring supplemental oxygen; 3: Non-ICU hospital ward (or "ready for hospital ward") requiring supplemental oxygen; 4: ICU or non-ICU hospital ward, requiring non-invasive ventilation or high-flow oxygen; 5: ICU, requiring intubation and mechanical ventilation; 6: ICU, requiring ECMO or mechanical ventilation and additional organ support (e.g., vasopressors, renal replacement therapy); 7: Death

decreasing the oxygen requirements by $\geq 50 \%$. It is to be noted that the first dose was effective without the need to a second dose in nearly $70 \%$ of the patients in the largest two study, namely the RECOVERY and REMAP-CAP studies $[5,6]$. (Table 2) However, further research is warranted to compare the outcomes of patients who received one dose and those who received two doses of TCZ.

\section{Conclusions and future perspectives}

TCZ is a useful drug in decreasing mortality and progression to invasive mechanical ventilation in patients with severe COVID-19 who are not yet invasively ventilated. However, its use in invasively ventilated does not show a clear benefit especially when administered after $>1$ day from mechanical ventilation. Thus, more research is warranted to explore the value of TCZ in severe cases who did not receive the drug early before- or within one day of invasive mechanical ventilation.

The main mechanism for TCZ in COVID-19 is modulation of the systemic inflammation; however, some studies reported positive response to the drug despite inclusion of patients who did not have documented cytokine storm.
Furthermore, even the studies which stipulated the presence of severe inflammation did not use the same cutoff values. Therefore, restricting the use of TCZ in patients with elevated inflammatory markers is not supported by strong evidence and it is warranted to investigate and/ or re-analyze the role of the drug in patients with severe COVID-19 and no signs of systemic inflammation.

TCZ is used in a dose of $8 \mathrm{mg} / \mathrm{kg}$ which can be repeated if there was no clinical improvement. However, there are no clear criteria for judgment of the success of the first dose which was defined in one study by decrease of oxygen requirements by 50\% and left to the physician judgment in all other studies. More analyses of the currently present data and new studies should compare the outcomes of single versus two doses of the drug.

Being a drug with a major effect on gross outcomes in a serious pandemic with millions of mortalities, TCZ should be meticulously investigated to reach definitive indications of administration of the first and second doses to avoid drug overuse, shortage, and side effects.

Funding This research did not receive any specific grant from funding agencies in the public, commercial, or not-for-profit sectors. 


\section{Declarations}

Conflict of interest The authors declare that they have no conflict of interest with this work.

\section{References}

1. Hopkins J. COVID-19 Map - Johns Hopkins Coronavirus resource Center [Internet]. Johns Hopkins Coronavirus Resource Center. (2020). https://coronavirus.jhu.edu/map.

2. Thepmankorn P, Bach J, Lasfar A, Zhao X, Souayah S, Chong ZZ, Souayah N. Cytokine storm induced by SARS-CoV-2 infection: the spectrum of its neurological manifestations. Cytokine. 2021;138:155404.

3. RECOVERY Collaborative Group, Horby P, Lim WS, Emberson JR, Mafham M, Bell JL, Linsell L, Staplin N, Brightling C, Ustianowski A, Elmahi E, Prudon B, Green C, Felton T, Chadwick D, Rege K, Fegan C, Chappell LC, Faust SN, Jaki T, Jeffery K, Montgomery A, Rowan K, Juszczak E, Baillie JK, Haynes R, Landray MJ. Dexamethasone in hospitalized patients with Covid19. N Engl J Med. 2021;384:693-704.

4. WHO Working Group on the Clinical Characterisation and Management of COVID-19 infection. A minimal common outcome measure set for COVID-19 clinical research. Lancet Infect Dis. 2020;20(8):192-7.

5. RECOVERY Collaborative Group. Tocilizumab in patients admitted to hospital with COVID-19 (RECOVERY): a randomised, controlled, open-label, platform trial. Lancet. 2021;397:1637-45.

6. REMAP-CAP Investigators, Gordon AC, Mouncey PR, Al-Beidh F, Rowan KM, Nichol AD, Arabi YM, Annane D, Beane A, van Bentum-Puijk W, Berry LR, Bhimani Z, Bonten MJM, Bradbury CA, Brunkhorst FM, Buzgau A, Cheng AC, Detry MA, Duffy EJ, Estcourt LJ, Fitzgerald M, Goossens H, Haniffa R, Higgins AM, Hills TE, Horvat CM, Lamontagne F, Lawler PR, Leavis HL, Linstrum KM, Litton E, Lorenzi E, Marshall JC, Mayr FB, McAuley DF, McGlothlin A, McGuinness SP, McVerry BJ, Montgomery SK, Morpeth SC, Murthy S, Orr K, Parke RL, Parker JC, Patanwala AE, Pettilä V, Rademaker E, Santos MS, Saunders CT, Seymour CW, Shankar-Hari M, Sligl WI, Turgeon AF, Turner AM, van de Veerdonk FL, Zarychanski R, Green C, Lewis RJ, Angus DC, McArthur CJ, Berry S, Webb SA, Derde LPG. Interleukin-6 receptor antagonists in critically ill patients with COVID-19. N Engl J Med. 2021;384:1491-502.

7. Hermine O, Mariette X, Tharaux P-L, Resche-Rigon M, Porcher R, Ravaud P, CORIMUNO-19 Collaborative Group. Effect of tocilizumab vs. usual care in adults hospitalized with COVID-19 and moderate or severe pneumonia: a randomized clinical trial. JAMA Intern Med. 2021;181:32-40.

8. Salama C, Han J, Yau L, Reiss WG, Kramer B, Neidhart JD, Criner GJ, Kaplan-Lewis E, Baden R, Pandit L, Cameron ML, Garcia-Diaz J, Chávez V, Mekebeb-Reuter M, Lima Menezes F, Shah R, González-Lara MF, Assman B, Freedman J. Tocilizumab in patients hospitalized with Covid-19 pneumonia. N Engl J Med. 2021;384:20-30

9. Soin AS, Kumar K, Choudhary NS, Sharma P, Mehta Y, Kataria S, Govil D, Deswal V, Chaudhry D, Singh PK, Gupta A, Agarwal V, Kumar S, Sangle SA, Chawla R, Narreddy S, Pandit R, Mishra V, Goel M, Ramanan AV. Tocilizumab plus standard care versus standard care in patients in India with moderate to severe COVID-19-associated cytokine release syndrome (COVINTOC): an open-label, multicentre, randomised, controlled, phase 3 trial. Lancet Respir Med. 2021;9:511-21.
10. Veiga VC, Prats JAGG, Farias DLC, Rosa RG, Dourado LK, Zampieri FG, Machado FR, Lopes RD, Berwanger O, Azevedo LCP, Avezum Á, Lisboa TC, Rojas SSO, Coelho JC, Leite RT, Carvalho JC, Andrade LEC, Sandes AF, Pintão MCT, Castro CG, Santos S V., de Almeida TML, Costa AN, Gebara OCE, de Freitas FGR, Pacheco ES, Machado DJB, Martin J, Conceição FG, Siqueira SRR, Damiani LP, Ishihara LM, Schneider D, de Souza D, Cavalcanti AB, Scheinberg P, Coalition covid-19 Brazil VI Investigators. Effect of tocilizumab on clinical outcomes at 15 days in patients with severe or critical coronavirus disease 2019: randomised controlled trial. BMJ. 2021;372:n84.

11. Rosas IO, Bräu N, Waters M, Go RC, Hunter BD, Bhagani S, Skiest D, Aziz MS, Cooper N, Douglas IS, Savic S, Youngstein T, Del Sorbo L, Cubillo Gracian A, De La Zerda DJ, Ustianowski A, Bao M, Dimonaco S, Graham E, Matharu B, Spotswood H, Tsai L, Malhotra A. Tocilizumab in hospitalized patients with severe Covid-19 pneumonia. N Engl J Med. 2021;384:1503-16.

12. Stone JH, Frigault MJ, Serling-Boyd NJ, Fernandes AD, Harvey L, Foulkes AS, Horick NK, Healy BC, Shah R, Bensaci AM, Woolley AE, Nikiforow S, Lin N, Sagar M, Schrager H, Huckins DS, Axelrod M, Pincus MD, Fleisher J, Sacks CA, Dougan M, North CM, Halvorsen Y-D, Thurber TK, Dagher Z, Scherer A, Wallwork RS, Kim AY, Schoenfeld S, Sen P, Neilan TG, Perugino CA, Unizony SH, Collier DS, Matza MA, Yinh JM, Bowman KA, Meyerowitz E, Zafar A, Drobni ZD, Bolster MB, Kohler M, D'Silva KM, Dau J, Lockwood MM, Cubbison C, Weber BN, Mansour MK, BACC Bay Tocilizumab Trial Investigators. Efficacy of tocilizumab in patients hospitalized with Covid-19. N Engl J Med. 2020;383:2333-44.

13. Salvarani C, Dolci G, Massari M, Merlo DF, Cavuto S, Savoldi L, Bruzzi P, Boni F, Braglia L, Turrà C, Ballerini PF, Sciascia R, Zammarchi L, Para O, Scotton PG, Inojosa WO, Ravagnani V, Salerno ND, Sainaghi PP, Brignone A, Codeluppi M, Teopompi E, Milesi M, Bertomoro P, Claudio N, Salio M, Falcone M, Cenderello G, Donghi L, Del Bono V, Colombelli PL, Angheben A, Passaro A, Secondo G, Pascale R, Piazza I, Facciolongo N, Costantini M, RCT-TCZ-COVID-19 Study Group. Effect of tocilizumab vs. standard care on clinical worsening in patients hospitalized With COVID-19 pneumonia: a randomized clinical trial. JAMA Intern Med. 2021;181:24-31.

14. Oberhoffer M, Karzai W, Meier-Hellmann A, Bögel D, Faßbinder J, Reinhart K. Sensitivity and specificity of various markers of inflammation for the prediction of tumor necrosis factor- $\alpha$ and interleukin- 6 in patients with sepsis. Crit Care Med. 1999;27:1814-8.

15. Ahnach M, Zbiri S, Nejjari S, Ousti F, Elkettani C. C-reactive protein as an early predictor of COVID-19 severity. J Med Biochem. 2020;39:500.

16. Ruan Q, Yang K, Wang W, Jiang L, Song J. Clinical predictors of mortality due to COVID-19 based on an analysis of data of 150 patients from Wuhan. China Intensive Care Med. 2020;46:846-8.

17. Mariette X, Hermine O, Tharaux P-L, Resche-Rigon M, Steg PG, Porcher R, Ravaud P. Effectiveness of tocilizumab in patients hospitalized With COVID-19: a follow-up of the CORIMUNO-TOCI-1 randomized clinical trial. JAMA Intern Med. 2021;384:1491-502.

Publisher's Note Springer Nature remains neutral with regard to jurisdictional claims in published maps and institutional affiliations. 